\title{
Znanstveni aktivizam studenata Medicinskog fakulteta Sveučilišta u Rijeci
}

\section{Student Scientific Activities at Faculty of Medicine of the University of Rijeka}

\author{
Ema Karmelić
}

\begin{abstract}
Sažetak. Povijest studentskog aktivizma pri Medicinskom fakultetu u Rijeci, pa time i znanstveno-istraživačka aktivnost naših studenata, seže od samih začetaka Fakulteta. Danas na Fakultetu djeluju četiri studentske udruge koje tijekom godine organiziraju pedesetak studentskih projekata. Kruna tih aktivnosti su studentski kongresi koji populariziraju znanost među studentima te ih uče o neraskidivoj vezi znanstvenih istraživanja, akademskog života i medicine. Oni pružaju priliku studentima da učine prve znanstvene korake u svojoj kući, prezentirajući radove i istraživanja pred širokom međunarodnom publikom. Upravo mogućnost upoznavanja i povezivanja budućih kolega i mladih znanstvenika na međunarodnoj razini stvara temelje za njihov osobni razvoj, kao i za napredak znanosti. U posljednjih devet godina studenti našeg fakulteta organizirali su devet Kongresa prehrane i kliničke dijetoterapije, osam Kongresa neuroznanosti, tri Kongresa hitne medicine, Kongres biomedicine, dva Kongresa dentalne medicine, dva Kongresa okolišnog zdravlja, Kongres zaštite zdravlja, šest Internih simpozija studenata Medicinskog fakulteta i Fakulteta zdravstvenih studija, tri simpozija, a potom i tri Kongresa Studenti za ljudska prava te su sudjelovali u organizaciji triju Ljetnih škola intervencijske radiologije. Kao rezultat toga velik broj studenata uključio se u znanstveno-istraživačke projekte koje su prezentirali i na kongresima diljem regije. Kroz navedene kongrese prošlo je na stotine studenata koji su svojim aktivnim ili pasivnim sudjelovanjem ili pak kao dio organizacijskog odbora time dali svoj mali doprinos znanosti. Velik broj stranih studenata koji iz godine u godinu dolaze na naše kongrese ukazuje na njihovu kvalitetu i prepoznatljivost te na činjenicu da su postali svojevrsni brend Medicinskog fakulteta i Sveučilišta u Rijeci.
\end{abstract}

Ključne riječi: studentski aktivizam; studentski kongresi; znanstvena istraživanja

Abstract. History of student activism at the Faculty of Medicine in Rijeka, as well as the scientific research activity of our students, originates from the very beginnings of the Faculty. Today, there are four active student organisations at the Faculty, which organize around fifty student projects over the year. The most important of these are student congresses that promote science among students and teach them about the inseparable bond between scientific research, academic life and medicine. They give students the opportunity to take the first scientific steps in their home, presenting their research to a wide international audience. It is the opportunity to meet and connect future colleagues and young scientists at an international scale, which creates the foundation both for their personal and scientific development. In the past nine years, our students have organized nine Congresses of Nutrition and Clinical Dietotherapy, eight Congresses of Neuroscience, three Congresses of Emergency Medicine, one Congress of Biomedicine, two Congresses of Dental Medicine, two Congresses of Environmental Health, one Congress of Health Protection, six Internal Symposia of Students of the Faculty of Medicine and the Faculty of Health Sciences, three symposia and three "Students for Human Rights" Congress, and have participated in the organization of three Summer Schools of Interventional Radiology. As a result, a large number of students have been involved in scientific research that has been presented at congresses across the region and hundreds of students have passed through our congresses, either as active or passive participants, or as part of the organizing committees. Large numbers of foreign students attend our congresses every year, which indicates their good quality and distinctiveness and that they became a brand of both the Faculty of Medicine and the University of Rijeka.

Key words: scientific research; student activism; student congresses
Opća bolnica Karlovac, Karlovac

Dopisni autor:

Ema Karmelić, dr. med.

Opća bolnica Karlovac

Dr. Andrije Štampara 3, 47000 Karlovac e-mail: ema.karmelic@gmail.com

http://hrcak.srce.hr/medicina 
KRATKI POVIJESNI PRESJEK STUDENTSKOG

ZNANSTVENOG AKTIVIZMA NA

MEDICINSKOM FAKULTETU U RIJECI

Medicinski fakultet u Rijeci može se pohvaliti činjenicom da od svog osnutka potiče i podržava studente u njihovoj kreativnosti i ambicijama da studiranje bude iskustvo koje će im donijeti puno više od samog učenja te time stvara plodno tlo za studentski aktivizam. Među rijetkim smo fakultetima koji uistinu gaje kulturu i tradiciju student-

S obzirom na njihovu proaktivnost, nije iznenađujuće da su upravo studenti medicine bili prvi studentski prorektori i prodekani Sveučilišta i Fakulteta, dok su te funkcije postojale u prošlosti. S tih pozicija utjecali su na stvaranje pozitivnog okružja za popularizaciju znanosti, što je rezultiralo organiziranjem brojnih studentskih projekata i kongresa.

skog aktivizma, pa time i znanstveno-istraživačke aktivnosti naših studenata, što se danas očituje kroz rad i djelovanje čak četiriju studentskih udruga koje zajedno čine okosnicu studentskog aktivizma na Sveučilištu u Rijeci, ali i šire. To su studentske udruge: Fakultetski odbor svih studenata Medicinskog fakulteta u Rijeci (FOSS MedRi), Studentsko sportsko društvo SOSS (SSD SOSS), riječka podružnica Međunarodne udruge studenata medicine Hrvatska (engl. Croatian Medical Students' International Committee - CroMSIC Rijeka) te Hrvatska udruga studenata dentalne medicine (engl. Croatian Association of Dental Students for International Activities and Exchange-CROADS).

Studentska udruga FOSS MedRi najveća je i najstarija studentska udruga na Sveučilištu, a započela je svoj rad s prvim koracima fakulteta $u$ 60-im godinama prošloga stoljeća. Danas pod motom "studenti za studente“ članovi udruge organiziraju preko trideset projekata i aktivnosti godišnje i to edukativnog, stručnog, znanstvenog, javnozdravstvenog, preventivnog, međunarodnog, kulturalnog, sportskog, društvenog i humanitarnog karaktera. Tradicionalno FOSS usko surađuje sa Studentskim zborom, predstavničkim tijelom studenata Medicinskog fakulteta te ople- menjuje život na fakultetu brinući se ne samo za bogat izvannastavni sadržaj, već i za kvalitetu izvođenja nastave, zaštitu prava studenata te bolji standard studiranja, na dobrobit i u interesu svih studenata.

Istraživanjem povijesti i rada naših studenata i studentskih organizacija u starim monografijama fakulteta mogu se pronaći zapisi o djelovanju različitih studentskih sekcija unutar studentske organizacije. Tako se u Monografiji fakulteta iz 1975. godine spominju sekcija za sport, društvo demonstratora, sekcija za kulturu i zabavu, sekcija za standard, skriptarska sekcija, sekcija za Speculum, sekcija za narodnu odbranu, ideološko politička sekcija i one relevantnije za korijene znanstvenog aktivizma naših studenata: klub narodnog zdravlja, kongresni odbor te sekcija za naučno istraživački rad. Spominje se i sudjelovanje naših studenata na kongresima studenata medicine i stomatologije Jugoslavije, za što su dobivali i nagrade Sveučilišta u Rijeci ${ }^{1}$. U Monografiji iz 1995. godine piše se o postojanju Odbora za znanstvenu i strukovnu međunarodnu suradnju unutar FOSS-a te sudjelovanju u organizaciji Svjetskog kongresa studenata medicine u Opatiji, Ljetne škole biomedicinskih znanosti, Hrvatskom međunarodnom kongresu studenata medicine CISS kao i organizaciji vrlo uspješne Ljetne škole ratne medicine (engl. "War medicine - Croatian Experience"), u kojoj je sudjelovao velik broj naših nastavnika koji su kroz niz kvalitetnih predavanja opisali vlastita iskustva iz ratnih godina prošlog stoljeća².

U Monografiji iz 2005. godine postoji podatak kako je 80-ih godina u FOSS-u postojala i sekcija „Mladi istraživači“. Ipak, u tim godinama dominirajući projekt bio je Speculum, najčitanije i najtraženije glasilo studenata koje je postiglo veliku tiražu zahvaljujući svojim oštrim tekstovima, smionim iznošenjem kontroverzi te specifičnim i bespoštednim internim fakultetskim humorom ${ }^{3}$. Upravo kroz stare brojeve Speculuma možemo pratiti daljnji razvoj studentskog aktivizma na Medicinskom fakultetu. Kroz 2000-ite FOSS organizira sve veći broj složenih projekata te samim time raste broj projekata vezanih uz popularizaciju znanosti. Organiziraju se brojna predavanja, seminari, tematske tribine i sudjeluje u organizaciji mnogobrojnih međunarodnih kongresa na 
ovim područjima ${ }^{3}$. Tih se godina formiraju novi odbori u FOSS-u, koji i danas čine njegove "stupove“. To su Nastavni odbor svih studenata (NOSS), Informatički odbor svih studenata (IOSS), Sportski odbor svih studenata (SOSS) te Znanstveni odbor svih studenata (ZOSS), koji nastoji aktivno poticati i uključivati studente u znanstveno-istraživački rad.

\section{ZNANSTVENI ODBOR SVIH STUDENATA}

$$
\text { (ZOSS) }
$$

Znanost i znanstvena istraživanja sastavni su dio akademskog života i zajednice. U ovoj eri brzog tehnološkog napretka, koji prate velika i svakodnevna znanstvena postignuća, važno je motivirati studente na bavljenje znanošću, ali i omogućiti im da ta znanja dijele s drugima. Evidentno je da su studenti Medicinskog fakulteta u Rijeci oduvijek bili vrlo osviješteni u tom smislu.

Od svih odbora unutar FOSS-a upravo je ZOSS bio najaktivniji u posljednjih desetak godina. $U$ tom razdoblju povjerenici za ZOSS bili su: Igor Salopek, Marija Rogoznica, Dora Karmelić, Hrvoje Omrčen, Ivan Franin i Maja Ploh, koja ga i trenutno vodi.

Glavni cilj ZOSS-a je afirmacija znanstveno-istraživačkog rada među studentima i pružanje pomoći pri njihovom znanstvenom napredovanju tijekom studija ${ }^{4}$. Misija je bila stvoriti platformu kreativnog studiranja svima koji medicinu promišljaju kao neraskidiv spoj znanosti i struke, utemeljen na znanstvenoj metodologiji. Pod motom „Od informacije do publikacije“ pokreće se niz novih projekata koji postaju servis svim studentima za uključivanje u znanstveno-istraživački rad ${ }^{5}$.

U starim brojevima Speculuma spominju se projekti koji, nažalost, nikada nisu u potpunosti zaživjeli, iako su ih mnogi pokušali pokrenuti. To su: „Registar znanstvenih projekata“ u kojem studenti mogu pronaći istraživanja po pojedinim mentorima ili katedrama kojima bi se htjeli priključiti, „Registar studenata“ koji se bave znanstvenim radom, „Baza podataka“ sa svim objavljenim studentskim radovima, „Kalendar studentskih kongresa" te studentske znanstvene sekcije koje su trebale biti svojevrsni inkubator znanstvenih radova. Planiralo se započeti s tri sekcije: „Sekcija za neuroznanost", „Sekcija za internu medicinu i onkologiju“ te „Sekcija za mikrobiologiju, infektologiju i imunologiju“4,5.
Unatoč projektima koji nisu zaživjeli, tih godina ZOSS-ovci su, vođeni zanosom i ljubavi prema znanosti i medicini, bili puni novih ideja, zOSS je tada procvjetao. No nije ZOSS bio jedini koji je prosperirao. U 2008. godini u časopisu Medicina Fluminensis dogodile su se mnogobrojne promjene. Novi Glavni urednik, novi Urednički odbor, novi kriteriji, novi ciljevi i nov izgled časopisa podigli su standard publiciranja Medicine na višu razinu, nastojeći pritom jednostavno i kvalitetno informirati medicinsku struku, liječnike, znanstvene novake te studente medicine ${ }^{6}$. Pokrenula se studentska sekcija Medicine čiji je zadatak bio poticanje studenata na razvoj kroz medicinsku znanost, što bi je učinilo svojevrsnim centrom edukacije $^{6}$. Kroz intenzivnu suradnju sa ZOSS-om razrađen je detaljni plan aktivnosti usmjeren na razvoj studentske znanstvene aktivnosti kako bi Medicina bila prvo mjesto sučeljavanja studenata s metodologijom, načinom pisanja i objavljivanja radova na svom jeziku u 'prijateljskom' okružju, s konačnim ciljem da se pokrene studentski znanstveni časopis na našem fakultetu ${ }^{6}$. lako ta ideja nije u potpunosti zaživjela tada, bilo je potrebno dati joj vremena da sazrije u našoj maloj akademskoj zajednici te skoro deset godina nakon, ove se ideje i ciljevi polako ostvaruju.

Srećom, većina ZOSS-ovih projekata zaživjela je i to na razini cijelog Sveučilišta, a neki od njih nisu strani ni građanima Rijeke. Među njima su zasigurno najpopularniji „ZOSS Filmske večeri“ i „ZosSci Caffei" koji su nastali s idejom da studentima pruže jedan drugačiji način učenja uz šalicu kave ili čašu vina. Tako su omiljeni riječki kafići postali mjesto u kojem studenti, djelatnici fakulteta i građani Rijeke u opuštenoj atmosferi uz zanimljiv film ili prezentaciju o odabranoj tematici, najčešće znanstvenoga tipa, mogu međusobno raspravljati te kreativno promišljati o medicini i znanosti i na taj način biti u tijeku sa znanstvenim otkrićima ${ }^{4,5}$.

ZOSS Express bio je jedan od popularnijih projekata kroz koji se ostvarivala suradnja s institucijama medicinsko-znanstvenog interesa u vidu stručnih ekskurzija ${ }^{4}$. Unatoč velikom interesu studenata za odlaske na ovakve ekskurzije, projekt se prestao provoditi u nedostatku zainteresiranih voditelja organizacijskog tima. No, u zamjenu za ZOSS Express, povremeno se organiziraju zajed- 
nički odlasci većeg broja sudionika na sve popularnije studentske kongrese diljem regije.

Svojevremeno su se organizirale također vrlo popularne, radionice „Kako napisati znanstveni rad“ u suradnji s časopisom Croatian Medical Journal kojima su se sudionicima približile sve tajne znanstvene metodologije kako bi mogli lakše kritički čitati znanstvene članke te svladati vještinu pisanja znanstvenog rada ${ }^{5}$.

Kroz rad ZOSS-a organizirala se prvi put u Rijeci popularna međunarodna javnozdravstvena akcija

Naši studenti sve aktivnosti organiziraju isključivo na volonterskoj bazi uz veliku količinu obaveza i odgovornosti koje studiji na Medicinskom fakultetu sa sobom nose, stoga u budućnosti treba paziti da povećanu kvantitetu kongresa ne prati pad u njihovoj kvaliteti. Štoviše, potrebno je kritički evaluirati organizacijske procese kongresa te osigurati njihov kvalitativni napredak.

„Movember", koja promovira važnost samopregleda, ranog otkrivanja i prevencije bolesti koje zahvaćaju mušku populaciju, a obilježava se puštanjem brkova tijekom studenoga. Cijeli mjesec organizirale su se tribine, predavanja i seminari za građane, a studenti i nastavnici Sveučilišta mogli su se uključiti u natječaj „Najbolji brk Sveučilišta u Rijeci“. Po završetku projekta uslijedio bi photosession i izrada kalendara s fotografijama studenata s najboljim brkovima.

\section{STUDENTSKI KONGRESI}

Kruna našeg studentskog znanstvenog aktivizma, po čemu smo postali prepoznatljivi diljem regije, naši su studentski kongresi. U posljednjih devet godina organizirali smo devet Kongresa prehrane i kliničke dijetoterapije, osam Kongresa neuroznanosti - NeuRi, tri Kongresa hitne medicine - HitRi, jedan Kongres biomedicine - BRIK, dva Kongresa dentalne medicine, dva Kongresa okolišnog zdravlja, jedan Kongres zaštite zdravlja - Sanitas, šest Internih simpozija studenata Medicinskog fakulteta i Fakulteta zdravstvenih studija - MedRi Znanstveni piknik, tri simpozija, a potom i tri Kongresa Studenti za ljudska prava te sudjelovali u organizaciji triju Ljetnih škola intervencijske radiologije. Svi navedeni događaji prilika su našim stu- dentima da u svojoj kući po prvi put sudjeluju na kongresu, bilo kao pasivni ili aktivni sudionici ili pak kao dio organizacijskog odbora, što je zaista potaknulo velik broj studenata na uključivanje u znanstvena istraživanja i pisanje radova koje potom izlažu ne samo na našim kongresima, već i diljem regije. Studenti su tako imali priliku usvojiti procese prijave rada na kongres, postupke recenzije i evaluacije rada te vještine izlaganja pred širokom, međunarodnom publikom. Našim kongresima stvorili smo platformu za učenje, dijeljenje novih saznanja i umrežavanje budućih mladih liječnika i znanstvenika sličnih afiniteta, što otvara prostor za kreiranje dugoročne suradnje u njihovom akademskom i profesionalnom životu. To su mjesta gdje se znanost i prilike za učenje kombiniraju s iskustvom, pozitivnom energijom, zabavom i uspomenama, rođenim iz zajedničke ljubavi prema medicini. Svi kongresi imaju sličan organizacijski program: sastoje se od plenarnih predavanja eminentnih predavača i stručnjaka, studentskih sekcija za usmena izlaganja i posterskih prezentacije, interaktivnih radionica, kao i društveno-zabavnog sadržaja.

Glavni izvor financiranja svih naših projekata je Studentski zbor Sveučilišta u Rijeci na čiji se natječaj za sufinanciranje studentskih projekata prijavljujemo iz godine u godinu. U 2018. godini prijavljeno je 30 projekata s Medicinskog fakulteta s ukupnom potražnjom sredstava u iznosu od $589.696,44$ kn, što je nešto više od ukupnog iznosa budžeta cijelog natječaja. Medicinskom fakultetu dodijeljeno je 188.405,39 kn, dakle trećina sredstava namijenjenih svim studentskim udrugama pri Sveučilištu. To je svakako pokazatelj da su naše udruge i naši projekti predvodnici studentskog aktivizma Sveučilišta u Rijeci. Drugi najveći izvor financija za naše projekte je Medicinski fakultet Sveučilišta u Rijeci, a zatim i Zaklada Sveučilišta, Studentski kulturni centar, Grad Rijeka i Primorsko-goranska županija, na čije se natječaje također prijavljujemo, a pomažu nam i mnogobrojne donacije privatnih tvrtki. Najveći iznos tih sredstava dobivaju upravo naši kongresi, što ukazuje na njihovu prepoznatljivost, kvalitetu i utjecaj koji imaju na popularizaciju znanosti te promoviranje Medicinskog fakulteta u Rijeci, Sveučilišta u Rijeci i u konačnici grada Rijeke. 
U studenom 2017. godine, pokrenula se suradnja između časopisa Medicina Fluminensis, ZOSS-a i naših kongresa, kojom je dogovoreno da pobjednički radovi dobiju priliku biti objavljeni u posebnom dodatku Medicine posvećenom studentskim radovima. Time je napokon zaživjela ona ideja iz 2008. godine. Sa željom da se studentske znanstvene aktivnosti, koje su uistinu zaživjele u posljednjih desetak godina, podignu na jednu novu, profesionalniju i kvalitetniju razinu, organizirana je i prva radionica s temom „Kako napisati dobar prikaz slučaja“. U planu su daljnje znanstvene edukacije za studente, kako bi znanstveni projekti, znanstvena istraživanja i pisanje znanstvenih radova bili što dostupniji studentima koji bi kroz njih stekli potrebno znanje, znanstveno-istraživačke vještine i znanstveno kritičko razmišljanje potrebno da postanu uspješni mladi liječnici i znanstvenici.

U nastavku članka slijedi kratki pregled svih studentskih kongresa i simpozija organiziranih na Medicinskom fakultetu u Rijeci.

\section{Studentski kongres Prehrana i klinička dijetoterapija}

Prvi Studentski kongres Prehrana i klinička dijetoterapija održao se u svibnju 2010. godine u organizaciji studenata istoimenog izbornog kolegija čiji je voditelj prof. dr. sc. Alen Ružić, dr. med., koji ih je vodio kroz proces organizacije kongresa. Prve kongrese studenti su organizirali u suradnji s riječkom podružnicom Studentske sekcije Hrvatskoga liječničkog zbora, no ubrzo je cjelokupnu organizaciju preuzeo FOSS. U organizaciju su krenuli s vizijom da naprave kongres koji će postati tradicionalan i kojem će studenti željni novih izazova aktivno posvetiti svoje slobodno vrijeme, što se i ostvarilo. U proteklih devet godina kongresom su predsjedavale četiri studentice, a kroz organizaciju je prošlo preko sto studenata (tablica 1). Na prvom kongre-

Tablica 1. Dosadašnji predsjednici Organizacijskog odbora Studentskog kongresa Prehrana i klinička dijetoterapija

\begin{tabular}{|c|c|}
\hline Godina & Predsjednici \\
\hline $2010 .-2011$. & Ema Ivandić \\
\hline $2012 .-2013$. & Maja Pin \\
\hline $2014 .-2015$. & Ana Oljača \\
\hline $2016 .-2017$. & Matea Tomasić \\
\hline 2018. & Marita Babić \\
\hline
\end{tabular}

su sudjelovalo je nešto više od šezdeset sudionika, a kasnijih godina taj se broj udvostručuje (slika 1). Sa željom da skrenu pozornost na važnost zdrave prehrane i njenu ulogu u zdravlju i bolesti, postavili su čvrste temelje danas najdugovječnijeg studentskog kongresa na našem fakultetu. S obzirom na to da ova tema predstavlja velik izazov za znanost, medicinsku struku i život

Ključ uspjeha u organizaciji naših kongresa, ali i ostalih projekata, je kontinuirani prijenos znanja i iskustava sa starijih na mlađe generacije. Time se osigurava kontinuiteta rada studentskih udruga i održavanja znanstvenostručnih projekata te pozicija Medicinskog fakulteta u Rijeci kao predvodnika u znanstvenim dostignućima Sveučilišta u Rijeci.

suvremenog čovjeka, Kongres je nepresušan izvor uvijek zanimljivih predavanja i radionica gdje se tijekom godina obradila široka paleta tema o prehrani s različitih biomedicinskih stajališta. Dio kongresa počeo se tijekom godina održavati u Opatiji, a u svom sedmom izdanju Kongres je pokrenuo službenu suradnju sa Specijalnom bolnicom za medicinsku rehabilitaciju, bolesti srca, pluća i reumatizma - Thalassotherapia Opatija, u čijim se prostorima odvija dio programa, te je time postao još atraktivniji stranim studentima (slika 2). Ono što ovaj Kongres čini popularnim među studentima je prepoznatljiva šarmantna

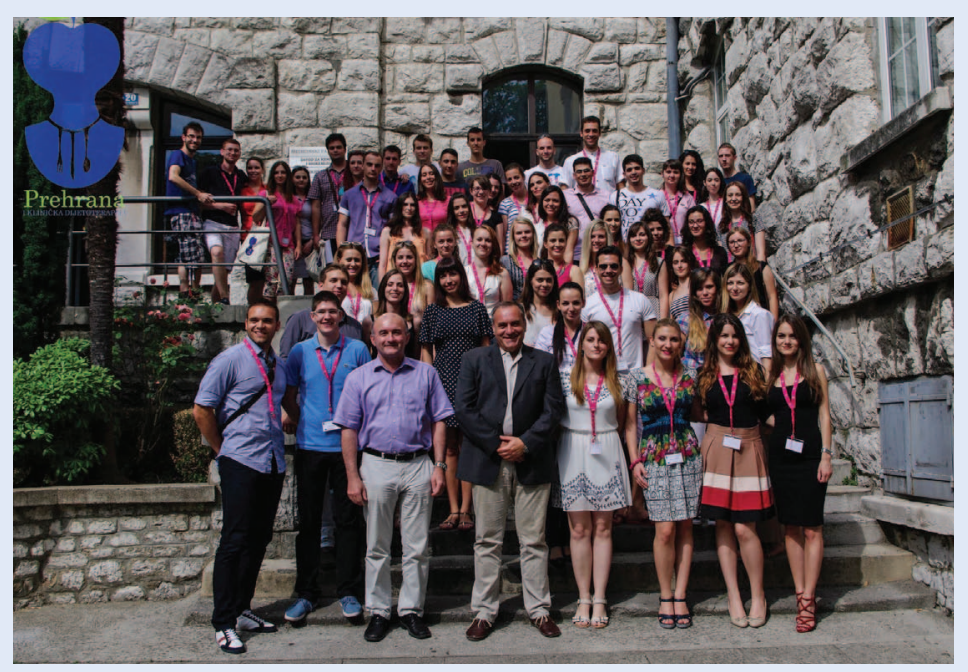

Slika 1. Otvorenje 7. studentskog kongresa Prehrana i klinička dijetoterapija, lipanj 2016. 


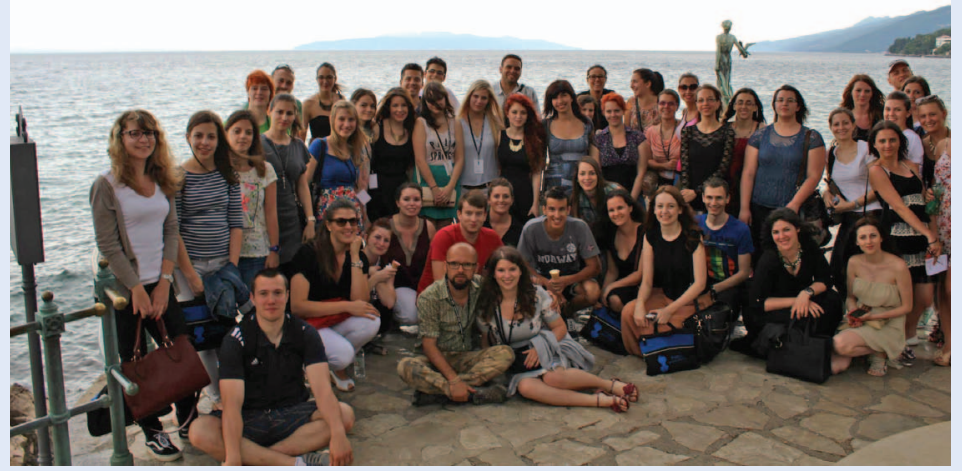

Slika 2. Posjet Opatiji na 5. studentskom kongresu Prehrana i klinička dijetoterapija, lipanj 2014.

atmosfera kojoj pridonosi obilje zdrave i ukusne hrane koju organizatori sami pripremaju te toplo i sunčano vrijeme kasnog proljeća ${ }^{7-9}$.

\section{Studentski kongres neuroznanosti - NeuRi}

Prvi kongres NeuRi organiziran je u travnju 2011. godine. Organizatori, članovi FOSS-a, djelujući pod motom 'Edukacija i iskustvo', željeli su postaviti kongresni okvir za stjecanje novih znanja i iskustava iz područja neuroznanostit ${ }^{10}$. Kongres se od samog početka održavao na dvije lokacije, na
Medicinskom fakultetu i u Psihijatrijskoj bolnici na Rabu. Zavidna organizacija kongresa ubrzo je stekla svoju prepoznatljivost i popularnost na fakultetima diljem regije, čime se stvorila travanjska tradicija okupljanja mladih neuroznanstvenih entuzijasta u Rijeci i Rabu koji, kroz zajedničku ljubav prema neuroznanosti, stvaraju međusobne suradnje i prijateljstva $(\text { slika } 3)^{10}$. Kongresom je do sada predsjedavalo troje studenata, s oko 150 članova u organizacijskim odborima (tablica 2).

Ciljana publika su studenti medicine i psihologije te ostalih srodnih biomedicinskih usmjerenja. Možemo reći da se kongres u svom trećem izdanju afirmirao kao svojevrsni brend našeg Fakulteta $\mathrm{i}$ Sveučilišta, privukavši rekordnih 300 sudionika! Tematika ovog kongresa vrlo je široka, no između ostalog teži senzibilizaciji sudionika na psihička, neurološka i cerebrovaskularna oboljenja. Problem društvene stigme pacijenata koji boluju od navedenih stanja i dalje je sveprisutan. Slušanje o tim temama na kongresu te posjet Psihijatrijskoj

Tablica 2. Dosadašnji predsjednici Organizacijskog odbora Studentskog kongresa neuroznanosti - NeuRi

\begin{tabular}{|c|c|}
\hline Godina & Predsjednici \\
\hline $2011 .-2014$. & Igor Salopek \\
\hline $2015 .-2016$. & Luka Fotak \\
\hline $2017 .-2018$. & Christina Isabell Jukić \\
\hline
\end{tabular}

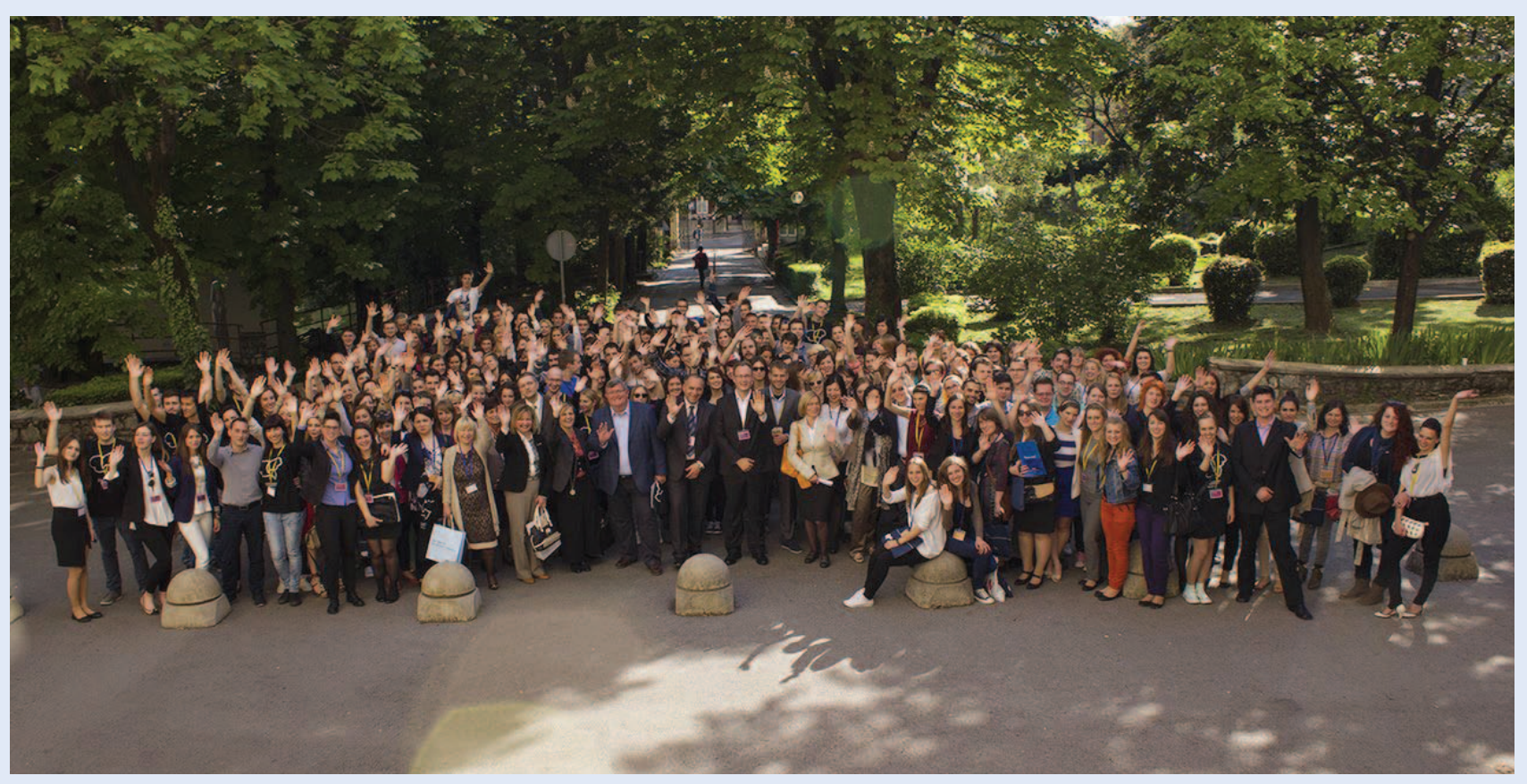

Slika 3. Otvorenje 4. studentskog kongresa neuroznanosti - NeuRi, travanj 2014. 
bolnici na Rabu gdje sudionici imaju priliku vidjeti rad takve ustanove i njene pacijente pridonose uklanjanju stigme i promociji mentalnog zdravlja.

\section{Kongres hitne medicine s međunarodnim sudjelovanjem - HitRi}

Kongres hitne medicine s međunarodnim sudjelovanjem prvi put je organiziran u travnju 2016. godine. Nastao je na inicijativu nekolicine studenata, članova udruge FOSS MedRi, koji su prepoznali potrebu za dodatnom edukacijom studenata $u$ području hitne medicine, kao i za većom posvećenosti praktičnom radu i kliničkim vještinama. Do sada su njime predsjedavale dvije studentice, s užim timom suradnika u organizacijskom odboru negoli je to u ostalim kongresima (tablica 3, slika 4).

Tablica 3. Dosadašnji predsjednici Organizacijskog odbora Kongresa hitne medicine - HitRi

\begin{tabular}{|c|c|}
\hline Godina & Predsjednici \\
\hline $2016 .-2017$. & Dušanka Beslać \\
\hline 2018. & Josipa Kajić \\
\hline
\end{tabular}

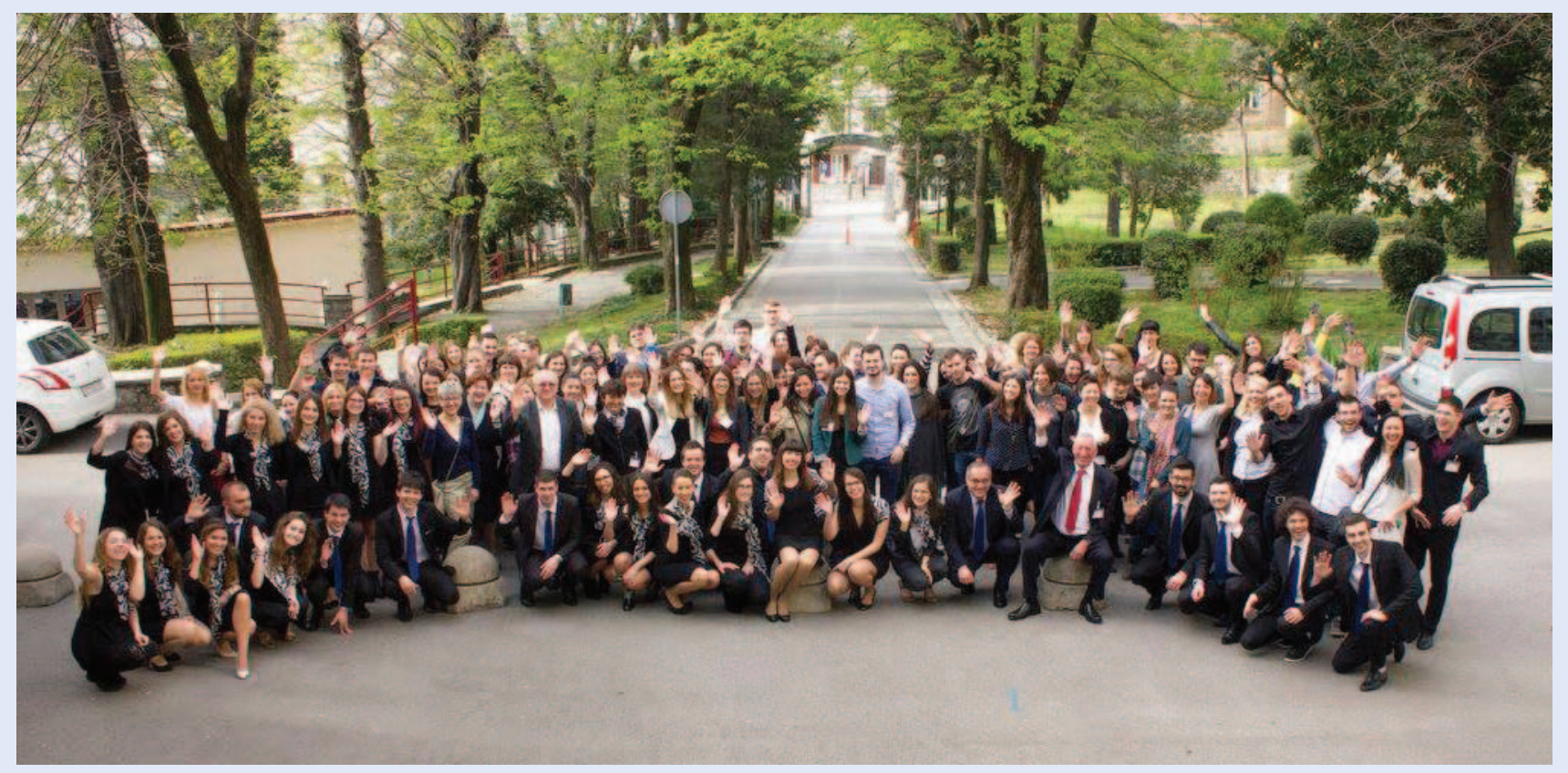

Slika 4. Organizacijski odbor 3. kongresa hitne medicine - HitRi, travanj 2018.

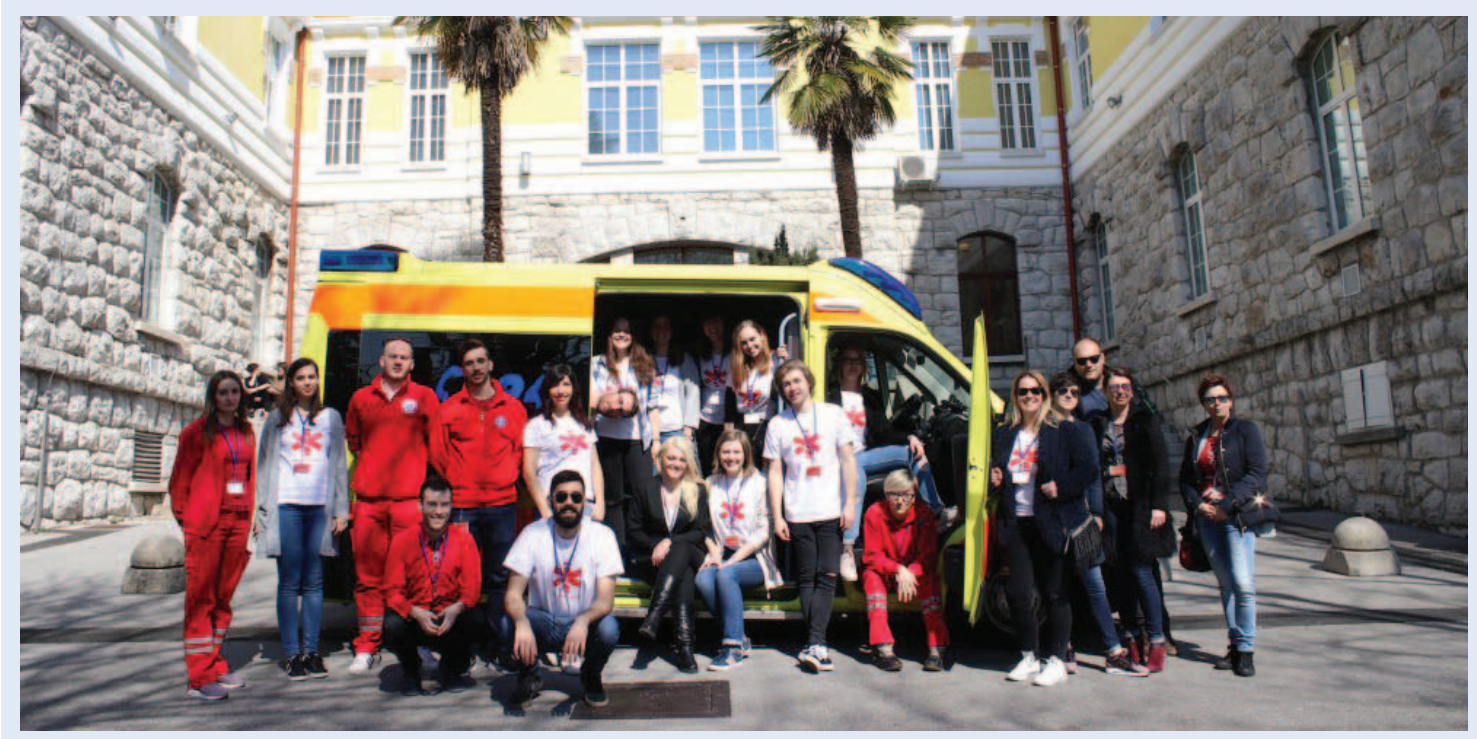

Slika 5. Otvorenje 1. kongresa hitne medicine - HitRi, travanj 2016. 
Kongres je organiziran u suradnji sa Zavodom za hitnu medicinu Primorsko-goranske županije, Kliničkim bolničkim centrom Rijeka i Medicinskim fakultetom, a namijenjen je studentima medicine, biomedicinskih i zdravstvenih studija te mladim liječnicima i ostalim djelatnicima medicinske struke (slika 5). Dobro poznavanje hitnih stanja pacijenata, njihovo pravovremeno prepoznavanje, adekvatno reagiranje i primjena odgovarajuće terapije u hitnim medicinskim situacijama, neophodna su znanja koja svaki zdravstveni djelatnik treba posjedovati i redovito obnavljati i nadopunjavati ${ }^{11}$. Kongres se ističe velikim brojem radionica gdje kroz rad u malim grupama svaki sudionik ima priliku vidjeti, naučiti i izvježbati praktične vještine $u$ hitnim stanjima. Time kongres pridonosi osposobljavanju studenata i mladih liječnika da po završetku studija budu što samostalniji u svom radu, da imaju potrebno samopouzdanje, znanja i vještine za rutinsko i adekvatno zbrinjavanje pacijenata.

\section{Međunarodni biomedicinski studentski kongres Rijeka - BRIK}

Naš najmlađi studentski kongres (engl. International Biomedical Student Congress Rijeka) održao se prvi put u studenom 2017. godine, na inicijati- vu studenata koji su potom postali članovi FOSS-a. Kongres je organiziran s idejom da se jednom godišnje na Medicinskom fakultetu u Rijeci okupe prosperitetni studenti i stručnjaci iz različitih dijelova svijeta kako bi predstavili svoja znanstvena otkrića i ideje iz područja biomedicine s ciljem umrežavanja budućih mladih znanstvenika ${ }^{12}$. S obzirom na potrebu za integriranjem medicinskih i biomedicinskih znanosti, ovim se kongresom nastoji stvoriti i ojačati suradnja interdisciplinarnih područja u medicini, stoga je kongres namijenjen studentima i znanstvenicima iz medicinskog, biomedicinskog, prirodnog i biotehnološkog područja12. Ovo je naš prvi kongres čiji je službeni jezik od njegovog prvog izdanja engleski, a privukao je nešto manje od stotinjak sudionika u prvoj godini održavanja (slika 6). Kongres se nastavlja organizirati i ove godine pod istim vodstvom i sličnim sastavom organizacijskog tima koji broji 15-ak studenata (tablica 4).

Tablica 4. Predsjednik Organizacijskog odbora Međunarodnog biomedicinskog studentskog kongresa Rijeka - BRIK

\begin{tabular}{|c|c|}
\hline Godina & Predsjednik \\
\hline 2017. -2018. & Tin Šimić \\
\hline
\end{tabular}

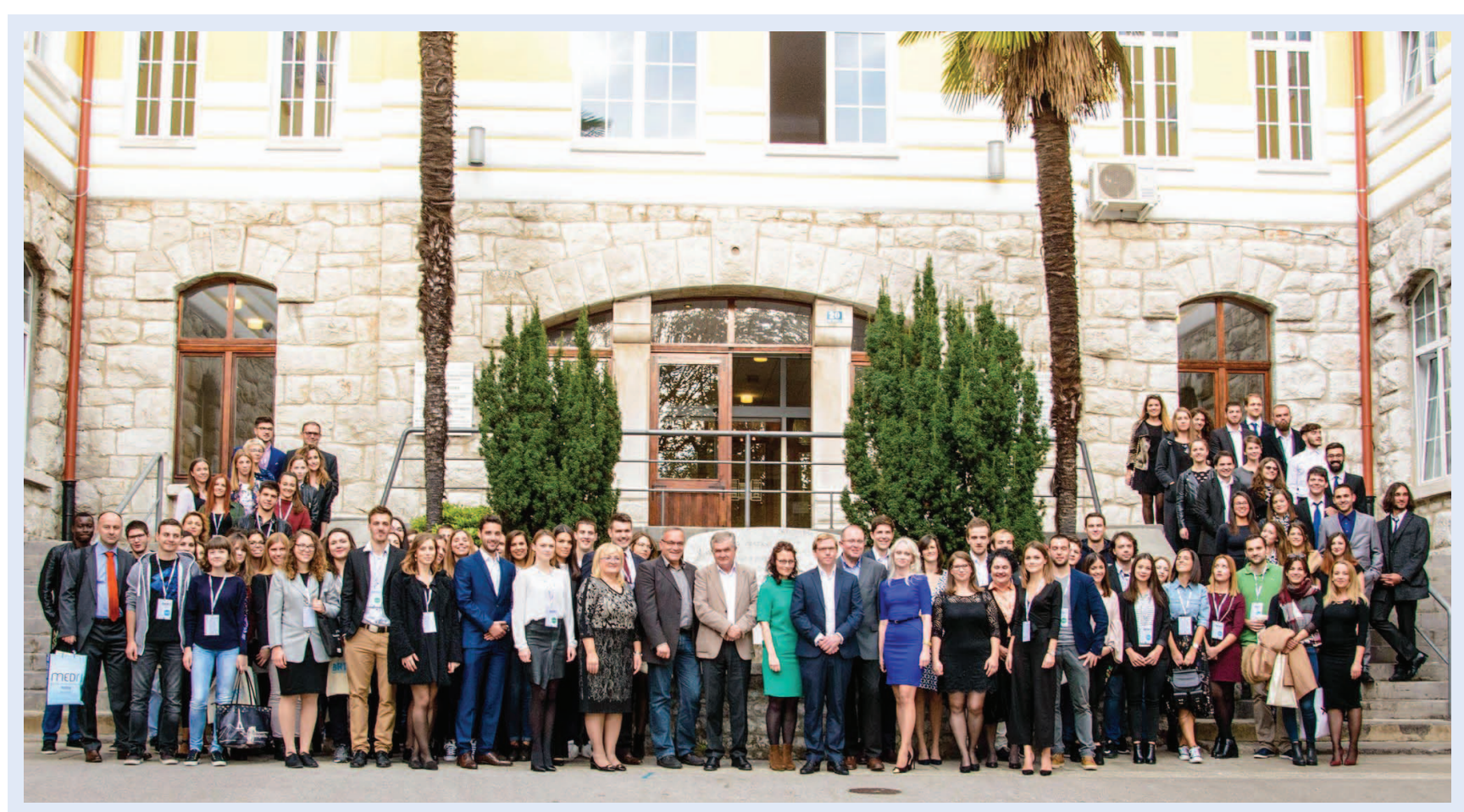

Slika 6. Otvorenje 1. međunarodnog biomedicinskog studentskog kongresa - BRIK, studeni 2017. 


\section{Studentski kongres zaštite zdravlja - Sanitas}

Sanitas - Studentski kongres zaštite zdravlja prvi put se održao u travnju 2018. godine u organizaciji studenata sanitarnog inženjerstva, članova udruge FOSS MedRi (tablica 5, slika 7). Kongres služi kao platforma za popularizaciju i poticanje istraživačkog rada među studentima sanitarnog inženjerstva i njemu srodnih studija (slika 8) ${ }^{13}$. U tijeku sa suvremenim trendovima kongres se fokusira na prevenciju i sprječavanje razvoja bolesti, odnosno na edukaciju građana o zaštiti vlastitog zdravlja, posljedice neodgovarajuće brige o svojem zdravstvenom stanju i niske zdravstvene pismenosti te postojećim preventivnim programima ${ }^{13}$.

Tablica 5. Predsjednica Organizacijskog odbora Studentskog kongresa zaštite zdravlja - Sanitas

\begin{tabular}{|c|c|}
\hline Godina & Predsjednica \\
\hline 2018. & Maša Lovrović \\
\hline
\end{tabular}

\section{Studentski kongres okolišnog zdravlja}

Ovaj kongres sastavni je dio većeg projekta studenata sanitarnog inženjerstva našeg fakulteta, Javnozdravstveni aspekti gospodarenja otpadom - zaštitimo zdravlje i okoliš, koji se prvi put realizirao u lipnju 2017. godine, u povodu obilježavanja Svjetskog dana zaštite okoliša (tablica 6). Problematika zbrinjavanja otpada, njegove posljedice na ekološki sustav i na zdravlje čovjeka aktualna

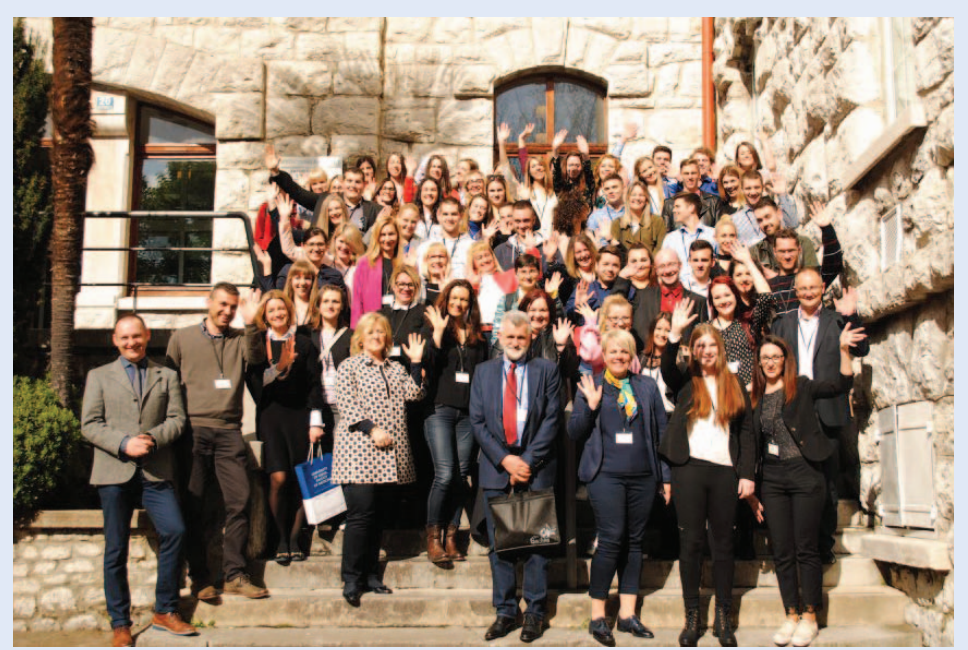

Slika 7. Organizacijski odbor Studentskog kongresa zaštite zdravlja - Sanitas, travanj 2018.

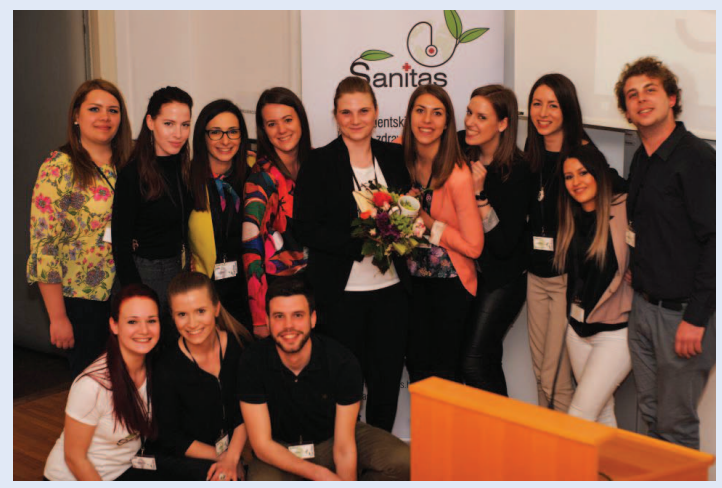

Slika 8. Otvorenje 1. studentskog kongresa zaštite zdravlja - Sanitas, travanj 2018.

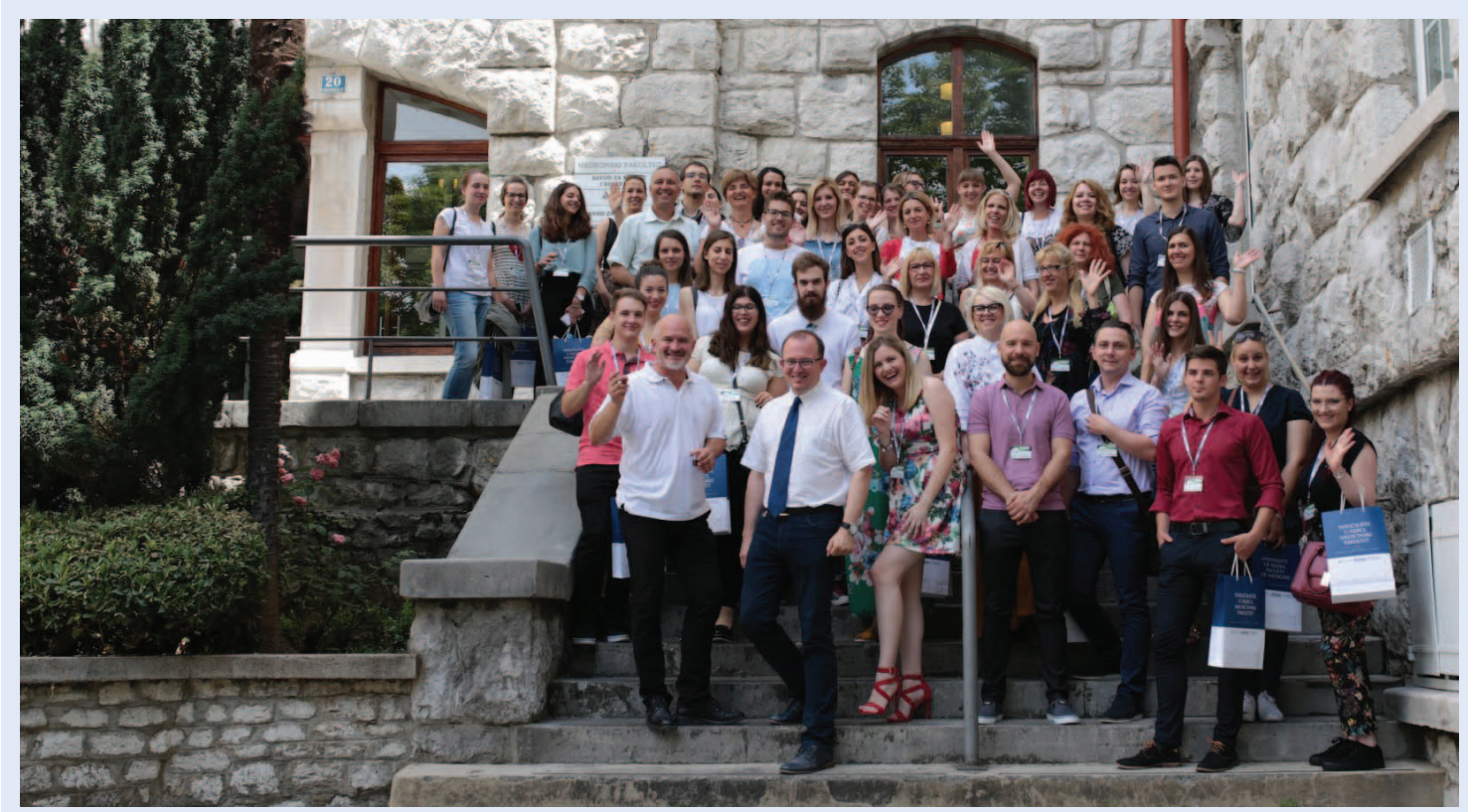

Slika 9. Otvorenje 2. studentskog kongresa okolišnog zdravlja, lipanj 2018. 
Tablica 6. Predsjednica Organizacijskog odbora Studentskog kongresa okolišnog zdravlja

\begin{tabular}{|c|c|}
\hline Godina & Predsjednica \\
\hline 2017. -2018. & Nikolina Špoljarić \\
\hline
\end{tabular}

su tema u svijetu i jedan od globalnih prioriteta. Cilj projekta je kroz vrlo bogat program kongresa u kojem sudjeluje multidisciplinarna lepeza predavača, educirati sudionike o pravilnom zbrinjavanju i gospodarenju otpadom povezujući javno zdravstvo s biomedicinom, ekologijom i tehničkim znanostima ${ }^{14}$. Kongres je osim studenata sanitarnog inženjerstva i srodnih studija, okupio i značajni broj građana (slika 9).

\section{Međunarodni kongres studenata dentalne medicine - RICON}

Prvi međunarodni kongres studenata dentalne medicine u Rijeci održao se 2013. godine u povodu

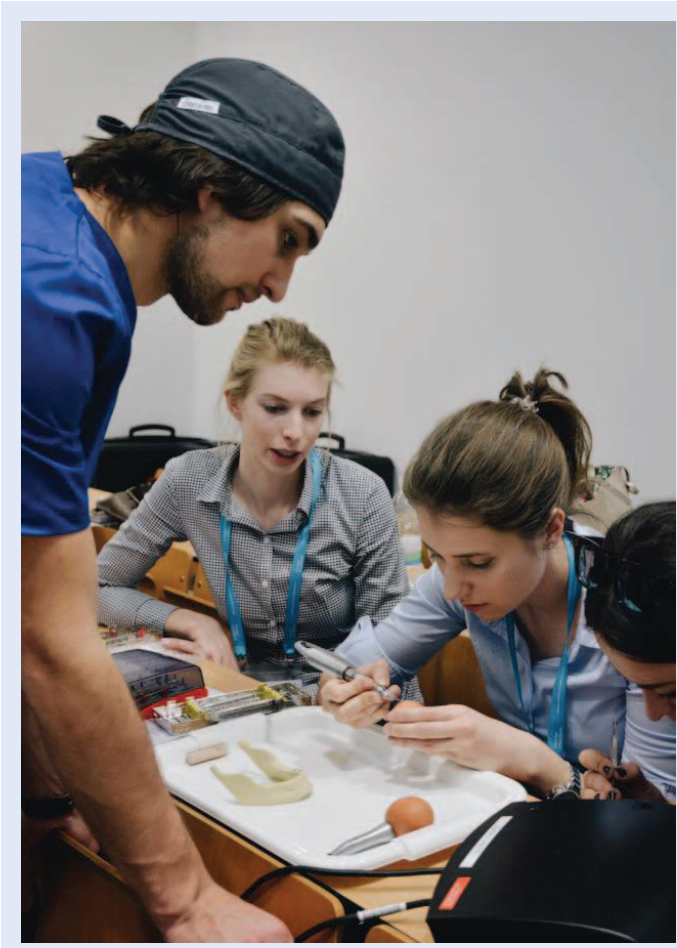

Slika 10. 2. međunarodni kongres studenata dentalne medicine-RICON, studeni 2017.

Tablica 7. Dosadašnji predsjednici Organizacijskog odbora Međunarodnog kongresa studenata dentalne medicine - RICON

\begin{tabular}{|c|c|}
\hline Godina & Predsjednici \\
\hline 2013. & Bernarda Mrak \\
\hline 2017. & Ivan Delić \\
\hline
\end{tabular}

obilježavanja 40 godina Studija dentalne medicine na Medicinskom fakultetu u Rijeci. Kongres su organizirali članovi Hrvatske udruge studenata dentalne medicine - CROADS. Na kongresu je sudjelovalo oko 200 studenata i doktora dentalne medicine. Drugi međunarodni kongres studenata dentalne medicine uslijedio je četiri godine kasnije pod novim nazivom RICON, kako bi ponovno omogućio studentima širenje znanja i povezivanje s kolegama iz cijele Europe (tablica 7). Tema kongresa bila je „Najnovije tehnologije i koncepti u dentalnoj medicini“. Naglasak je bio na mnogobrojnim radionicama kroz koje su studenti mogli svladati nove manualne vještine na najmodernijoj opremi, skupocjenim simulatorima i modelima koje su osigurali sponzori (slika 10) ${ }^{15}$. Bila je to još jedna prilika domaćim studentima da na vlastitom fakultetu predstave svoje radove javnim nastupom pred mnogobrojnom međunarodnom publikom.

\section{Kongres Studenti za ljudska prava}

Kongres Studenti za ljudska prava nastao je iz istoimenog simpozija koji su prvi put organizirali 2013. godine studenti Odbora za ljudska prava i mir udruge CroMSIC Rijeka (tablica 8, tablica 9). Cilj simpozija i kongresa je nadahnuti i podsjetiti sudionike kako svatko može dati svoj doprinos u očuvanju ljudskih prava koja su zbog nedostatka edukacije u današnjem društvu često zanemarena. To se možda najviše očituje u diskriminaciji određenih skupina ljudi ovisno o njihovu spolu, rodu, seksualnoj orijentaciji, boji kože, vjeroispovijesti, dobi, zdravstvenom i financijskom statusu, nacionalnoj pripadnosti ${ }^{16}$. Kongres je namijenjen studentima i djelatnicima svih fakulteta te građa-

Tablica 8. Predsjednici Organizacijskog odbora Simpozija Studenti za ljudska prava

\begin{tabular}{|c|c|}
\hline Godina & Predsjednici \\
\hline $2013 .-2014$. & Ivana Vujec \\
\hline 2015. & Eliša Papić \\
\hline
\end{tabular}

Tablica 9. Dosadašnji predsjednici Organizacijskog odbora Kongresa Studenti za ljudska prava

\begin{tabular}{|c|c|}
\hline Godina & Predsjednici \\
\hline 2016. & Eliša Papić \\
\hline $2017 .-2018$. & Dora Iljadica \\
\hline
\end{tabular}




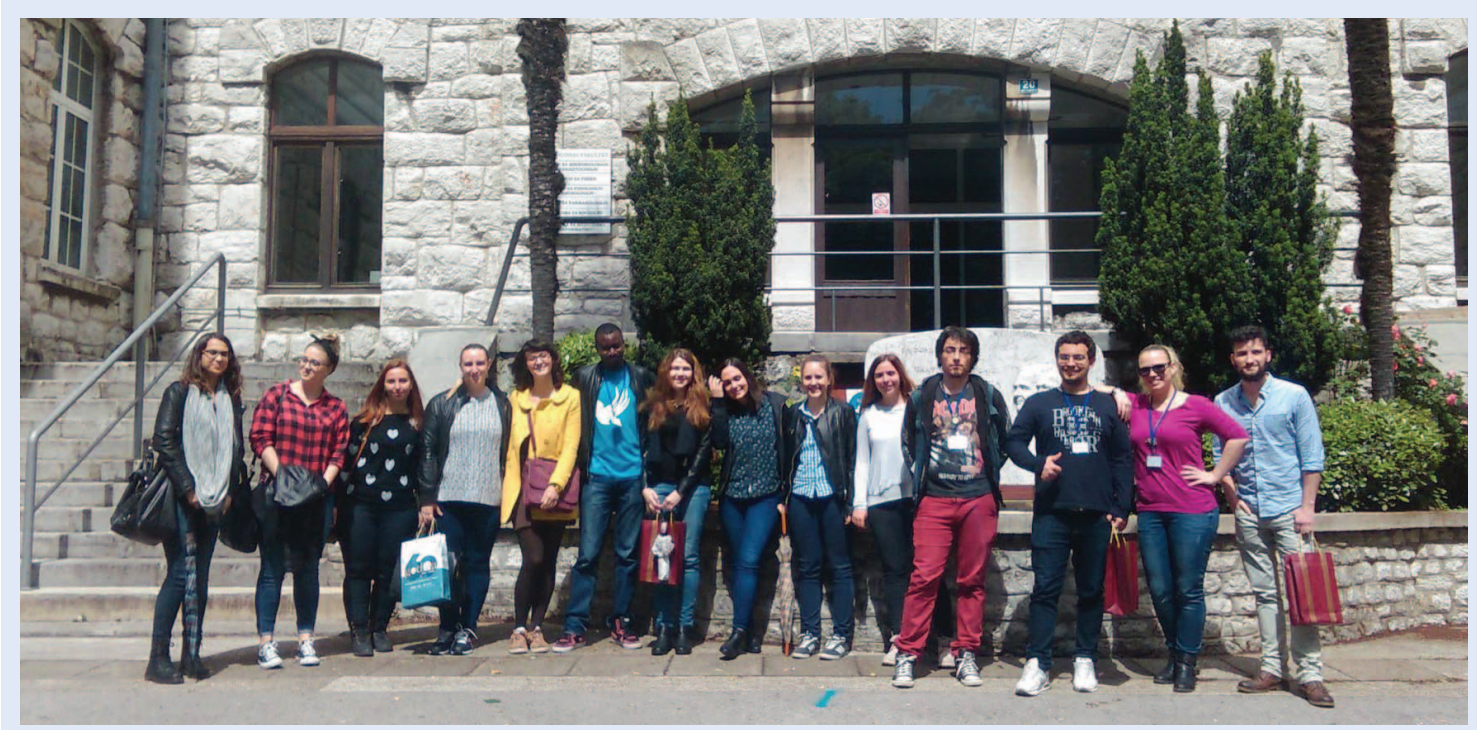

Slika 11. Otvorenje 1. kongresa Studenti za ljudska prava, svibanj 2016.

nima Rijeke. Mladi ljudi, a pogotovo studenti medicine, čiji je glavni zadatak štiti ljudsko zdravlje i život, moraju biti educirani, osviješteni i informirani o ovoj važnoj temi te bi u svom radu i djelovanju trebali propagirati zdrave društvene vrijednosti u težnji za stvaranjem boljeg, tolerantnijeg i sigurnijeg društva ${ }^{16}$. Ovaj kongres, nažalost, brojčano okuplja mali broj sudionika, no svaki sudionik koji sa sobom ponese znanje o toleranciji i ravnopravnosti u društvu, neprocjenjiv je dio zajednice (slika 11).

\section{MedRi Znanstveni PIKNIK}

MedRi Znanstveni PIKNIK jednodnevni je interni simpozij studenata Medicinskog fakulteta te kasnije, od njihovog odvajanja, i studenata Fakulteta zdravstvenih studija u Rijeci. Simpozij je nastao 2012. godine u organizaciji ZOSS-a s ciljem omogućavanja studentima da predstave znanstvene radove $i$ istraživanja kojima se bave ostalim studentima i nastavnicima našeg fakulteta. Time se postiže popularizacija znanosti među mlađim studentima, nastoji ih se inspirirati, pokazati im način na koji se mogu uključiti u znanstveni rad i ukazati da se zaista može i treba baviti znanošću za vrijeme studija. Ovaj simpozij, osim što pruža priliku studentima da svoje prve znanstvene korake učine upravo na našem fakultetu, promovira znanstvene radove studenata među nastavnim osobljem, koje često nije svjesno istraživanja $\mathrm{i}$ projekata kojima se studenti bave. Tradicionalno se održava u vrijeme obilježavanja Dana Medicinskog fakulteta u prosincu. Posljednje dvije godine, pod novim vodstvom, na simpoziju se održavaju i radionice osnovnih kliničkih vještina te je poprimio humanitarni karakter (tablica 10, slika 12). Umjesto kotizacija, za vrijeme simpozija, svi sudionici i slučajni prolaznici mogu ostaviti svoju novčanu donaciju, namijenjenu u humanitarne svrhe.

Tablica 10. Dosadašnji predsjednici Organizacijskog odbora MedRi znanstvenog piknika

\begin{tabular}{|c|c|}
\hline Godina & Predsjednici \\
\hline $2012 .-2014$. & Luka Fotak \\
\hline 2015. & Hrvoje Omrčen \\
\hline $2016 .-2017$. & Maja Ploh \\
\hline
\end{tabular}

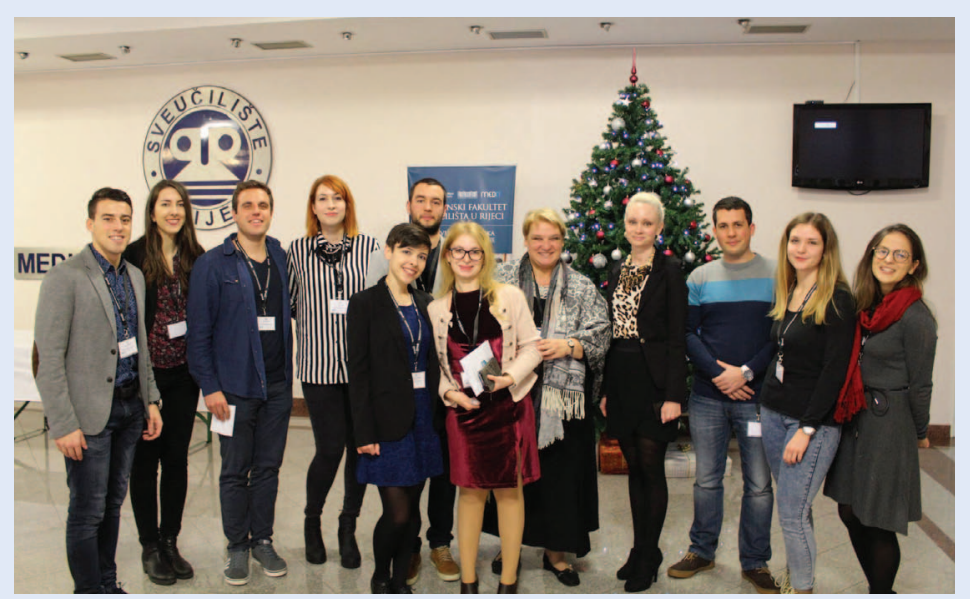

Slika 12. MedRi znanstveni piknik, prosinac 2017. 


\section{Ljetna škola intervencijske radiologije}

Ljetna škola intervencijske radiologije projekt je Kliničkog zavoda za radiologiju KBC-a Rijeka, Katedre za radiologiju Medicinskog fakulteta Rijeka i Univerzitetnog kliničkog centra Ljubljana. Organiza-

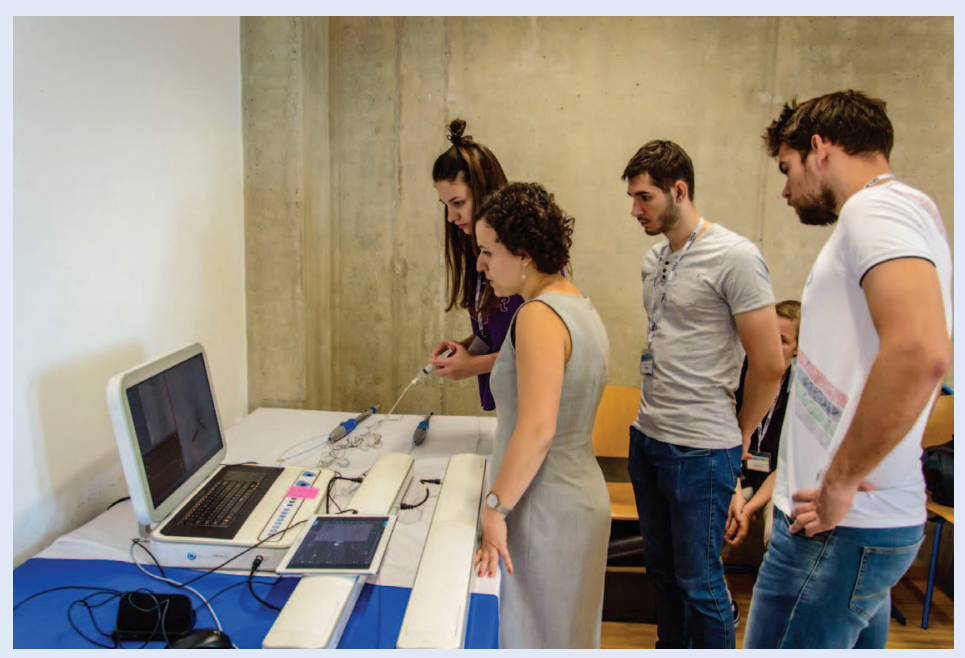

Slika 13. Ljetna škola intervencijske radiologije, lipanj 2018. ciji su se priključili i studenti udruge FOSS MedRi. Prva škola organizirala se 2016. godine kao dvodnevni edukacijski program namijenjen prvenstveno studentima završnih godina studija medicine kako bi se dodatno educirali u području minimalno invazivnih intervencijskih zahvata $u$ radiologiji i kardiologiji. Minimalno invazivni zahvati predstavljaju budućnost medicine, no o njima se još uvijek ne uči dovoljno za vrijeme studija. Za vrijeme Škole, osim što imaju priliku čuti predavanja vrhunskih predavača, studenti imaju priliku samostalno vježbati invazivne zahvate na profesionalnim simulatorima (slika 13). Upravo zbog rada na simulatorima za Školu se brzo pročulo i vrlo je popularna među studentima. Prve godine sudjelovati su mogli samo studenti Medicinskog fakulteta u Rijeci, a kasnije, zbog velikog interesa, sudjelovanje se proširilo na studente iz cijele regije, što daje međunarodni kontekst cijelom događaju i nudi priliku za umrežavanje mladih kolega.

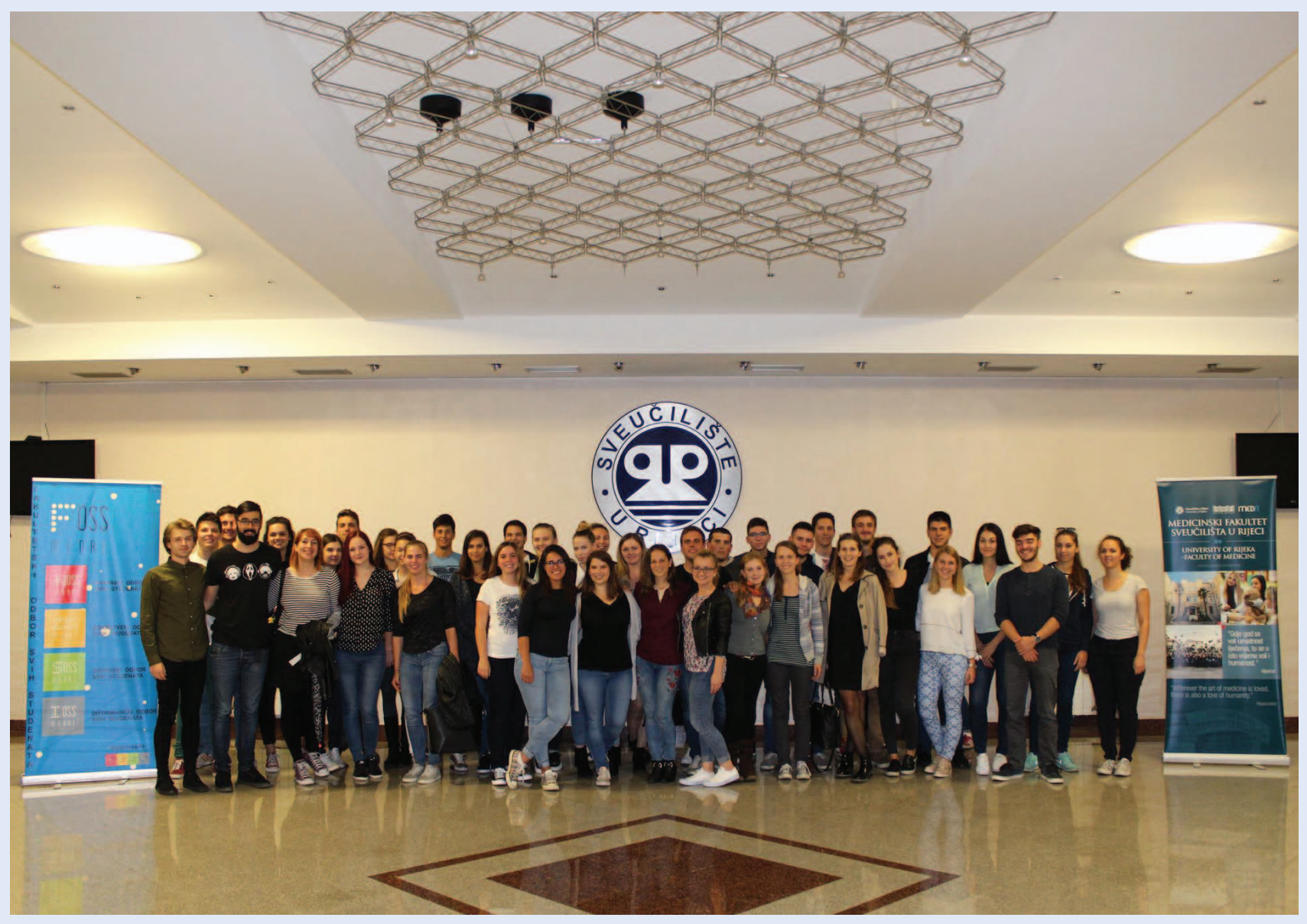

Slika 14. Članovi udruge FOSS MedRi, listopad 2017. 


\section{ZAHVALA}

Ovim putem htjela bih zahvaliti svim bivšim studentima, mojim prethodnicima, koji su neumorno radili na ispisivanju ove bogate povijesti studentskog aktivizma na Medicinskom fakultetu u Rijeci i nasljeđu koje su nam ostavili. Zahvaljujem kolegicama i kolegama, svojim prijateljima, koji su me uveli u svijet studentskog aktivizma već na početku studija medicine te svima onima koji su za vrijeme mog predsjedavanja FOSS-om i Studentskim zborom neumorno radili na osmišljavanju, realizaciji i organizaciji novih projekata, ali i održavanju tradicije onih koje smo naslijedili (slika 14). Zahvaljujem unaprijed i mlađim kolegama koji spremno preuzimaju odgovoran posao promocije medicine i znanosti u našem društvu. Na kraju, zahvaljujem svima koji su prepoznali trud i predanost naših studenata koje su uložili u organizaciju svih navedenih aktivnosti te ih kontinuirano podržavaju svojim sponzorstvima, partnerstvima i donacijama.

Izjava o sukobu interesa: autorica izjavljuje da ne postoji sukob interesa.

\section{LITERATURA}

1. Savez studenata. In: Wolf A (ed). Medicinski fakultet Rijeka. Rijeka: Medicinski fakultet, 1975;33.

2. Protić A. Studentske organizacije Medicinskog fakulteta u Rijeci. In: Sepčić J (ed). Medicinski fakultet u Rijeci 1955. - 1995. Rijeka: Medicinski fakultet, 1995;245-6.

3. FOSS MedRi, Fakultetski odbor svih studenata Medicinskog fakulteta u Rijeci. Studentske organizacije. In: Škrobonja A (ed). Medicinski fakultet Sveučilišta u Rijeci 1955. - 2005. Rijeka: Medicinski fakultet, 2005;238-41.

4. ZOSS osobna iskaznica, "Od informacije do publikacije", ZOSS - znanstveni odbor svih studenata. Speculum, Glasilo studenata Medicinskog fakulteta u Rijeci 2011;23.
5. Salopek I. Dobra znanstvena vibra - ZOSS MedRi. Speculum, Glasilo studenata Medicinskog fakulteta u Rijeci 2009;14.

6. Pereza N. „Medicina“ otvara vrata studentima. Speculum, Glasilo studenata Medicinskog fakulteta u Rijeci 2009;53-6.

7. Ivandić E. Prehrana i klinička dijetoterapija - studentski kongres. Speculum, Glasilo studenata Medicinskog fakulteta u Rijeci 2011;27.

8. Tomasić M. Predgovor. Zbornik sažetaka 8. Studentskog kongresa Prehrana i klinička dijetoterapija s međunarodnim sudjelovanjem; 2017. lipanj 16. - 18. Medicinski fakultet Sveučilišta u Rijeci, Rijeka 2017.

9. Oljača A. Predgovor. Zbornik sažetaka 5. Studentskog kongresa Prehrana i klinička dijetoterapija s međunarodnim sudjelovanjem; 2014. lipanj 13. - 15. Medicinski fakultet Sveučilišta u Rijeci, Rijeka 2014;8.

10. Salopek I. Welcome note. Abstract Book, $3^{\text {rd }}$ Student Congress of Neuroscience Rijeka, Rab; 2013 April 26 - 28. University of Rijeka, Faculty of Medicine, Rijeka 2013;9.

11. Beslać D. Predgovor. Knjiga sažetaka 2. Kongresa hitne medicine s međunarodnim sudjelovanjem, 31. ožujak 2. travnja 2017. Medicinski fakultet Sveučilišta u Rijeci, Rijeka 2017.

12. Šimić T. Welcome note, Abstract book, 1st International Biomedical Student Congress Rijeka, BRIK, 2017 November $2-4$. University of Rijeka, Faculty of Medicine, Rijeka 2017.

13. ] Sanitas.student.congress. [Internet]. Rijeka: Sanitas Student Congress of Health Protection; c2018 [cited 2018 Sept 29]. Available from: https://m.facebook. com/sanitas.student.congress/

14. Okolišno.zdravlje [Internet]. Rijeka: Javnozdravstveni aspekti gospodarenja otpadom - zaštitimo zdravlje i okoliš; c2018 [cited 2018 Sept 29]. Available from: https://m.facebook.com/okolisno.zdravlje/

15. Međunardoni kongres, Najnovije tehnologije u dentalnoj medicini dostupne studentima na RICON-u [Internet]. Rijeka; c2018 [cited 2018 Sept 29]. Available from: http://studentski.hr/studenti/vijesti/najnovije-tehnologije-u-dentalnoj-medicini-dostupne-studentima-na-ricon-u

16. Studenti kongresom žele osvijestiti pozitivne vrijednosti i afirmirati ljudska prava [Internet]. Rijeka; c2018 [cited 2018 Sept 29]. Available from: https://m.vecernji.hr/ amp/vijesti/studenti-kongresom-zele-osvijestiti-pozitivne-vrijednosti-i-afirmirati-ljudska-prava-1081634 